\title{
Postpurchase Dissonance pada Pengguna IPhone Ditinjau dari Kepribadian Tipe A dan Tipe B
}

\author{
Risma Evie Kusrina ${ }^{1}$, Muhammad Salis Yuniardi ${ }^{2}$, Alifah Nabilah Masturah ${ }^{3}$ \\ Fakultas Psikologi, Universitas Muhammadiyah Malang \\ e-mail: ${ }^{1}$ rismaevie@gmail.com
}

\begin{abstract}
In consumer behavior, it followed by postpurchase evaluation. When in the evaluation, there appears a doubt about the purchase decision on a product, and then an individual must be experiencing a postpurchase dissonance. The product used in this study is the iPhone. As for the factors that can influence postpurchase dissonance, one of them is the tendency of individual anxiety, which is caused by personality type. This study aims to determine the differences in iPhone users' student with type A and type B personalities in experiencing postpurchase dissonance. The analysis used causal comparative and determination of the subject used purposive sampling. The research subjects were iPhone users' students of Muhammadiyah Malang University, amount 125 subjects. This study used a postpurchase dissonance scale, also type $A$ and type $B$ personality scale. The analysis in this study used an independent sample ttest. The results showed that there was no difference in postpurchase dissonance in terms of type $A$ and type $B$ personality patterns with a significance value of 0.352 and $p=0,05(0,352>$ $0,05)$.
\end{abstract}

KEYWORDS postpurchase dissonance, type A and type B personality, iPhone users' student.

CITATION Kusrina, R., Yuniardi, M., \& Masturah, A. (2019). Postpurchase dissonance pada pengguna iphone ditinjau dari kepribadian tipe a dan tipe $b$. Cognicia, 7, (1), 30-49.

Dalam hidup bermasyarakat tentunya manusia melakukan halhal yang berkaitan dengan proses kehidupan guna memenuhi kebutuhan. Menurut Solomon (1999) proses keterlibatan seseorang atau kelompok dalam memilih, membeli, menggunakan atau membuang suatu produk, jasa/pelayanan, ideide, atau pengalaman dalam memuaskan kebutuhan dan keinginannya disebut sebagai perilaku konsumen. Perilaku manusia sebagai konsumen dari waktu ke waktu mengalami perubahan. Misalnya saja, dahulu kala konsumen dihadapkan pada pilihan merek produk yang jauh lebih sedikit dibandingan dengan pilihan produk sekarang. Oleh karena itu konsumen harus memikirkan dengan matang dalam memilih produk yang akan digunakannya.

Assael (1984) menjelaskan terdapat beberapa tahapan pengambilan keputusan hingga konsumen membeli suatu produk, yaitu: (1) tahap pengenalan kebutuhan (need rousal): individu mengenali kebutuhan yang harus dipenuhinya dan biasanya mulai memikirkan produk yang dikenal untuk kebutuhannya tersebut, (2) tahap pencarian informasi (consumer information processing): sesegera mungkin individu memiliki 
informasi yang luas mengenai produk dari kebutuhan yang dibutuhkan melalui iklan atau orang lain, (3) tahap evaluasi produk (brand evaluation): individu harus mempersempit kriteria yang paling sesuai dengan kebutuhan berdasarkan merekmerek alternatif yang ada, sehingga ia akan memilih alternatif yang sesuai, (4) pembelian (purchase): individu akan membeli merek yang disukai atau dipilih. Namun ada beberapa faktor yang dapat menunda pembelian seperti kekurangan dana atau ketidaktersediaan produk yang dicari, (5) evaluasi setelah pembelian (post-purchase evaluation): setelah pembelian, individu atau konsumen melakukan evaluasi terhadap produk yang dibeli. Apabila ia merasa puas, maka ada kemungkinan untuk dia mengulang pembelian di kemudian hari, begitu pula sebaliknya.

Jayanti (2014) dalam penelitiannya mengatakan bahwa tidak semua pembelian akan disusul oleh suatu kepuasan yang dialami oleh konsumen. Di antara pembelian, ada beberapa diantaranya yang berujung pada ketidakpuasan. Ketidakpuasan tersebut diwujudkan dengan bentuk kecemasan psikologis dari subjek yang diwawancarainya. Subjek tersebut mengatakan bahwa setelah pembelian, ia merasa tidak puas dengan barang yang dibeli karena apa yang diyakini sebelum membeli produk tidak sesuai dengan kenyataan yang ada pada produk yang telah mereka beli hingga memunculkan rasa ragu atas keputusan pembelian yang telah dilakukan. Hal tersebut menurut Assael (1984) merupakan bentuk dari disonansi pasca pembelian yang disebut postpurchase dissonance.

Sama halnya seperti wawancara personal pada Desember 2015 kepada D (mahasiswi 21 tahun) yang mengatakan bahwa ia justru mengungkapkan rasa ragu setelah membeli handphone merek tertentu, padahal waktu itu ada alternatif handphone merek lain. Kemudian ia merasa ragu dengan pilihannya karena ada beberapa fitur yang kurang maksimal. Namun akhirnya ia sadar bahwa ia terpengaruh oleh sales ketika proses memilih produk kala itu. Di kemudian hari ia tidak mau berlamalama larut dalam keraguan sehingga tetap memutuskan untuk memakai handphone yang dibelinya dengan cara mencari informasi untuk menguatkan keputusannya dalam membeli handphone merek tertentu tersebut.

Di era globalisasi ini teknologi semakin canggih dan berkembang pesat dalam masyarakat. Salah satu kemajuan teknologi yang sedang berkembang pesat saat ini adalah gadget maupun smartphone. Agusta dan Aris (2011), smartphone atau ponsel pintar adalah telepon genggam yang kemampuan dan fungsinya menyerupai komputer. Telepon pintar ini bekerja menggunakan seluruh perangkat lunak sistem operasi yang menyediakan standar dan mendasar bagi pengembang aplikasi. Telepon ini menyajikan fitur canggih seperti email, internet, ebook, kamera dan fitur lainnya. Smartphone biasanya dipahami sebagai ponsel dan bukan telepon rumah. Selama bertahun-tahun, konsep ponsel pintar terus berkembang sebagai perangkat tangan yang menjadi lebih canggih.

Nurbaity (2014) mengatakan bahwa teknologi yang memudahkan masyarakat tersebut sudah merambah pada dunia pendidikan seperti kalangan mahasiswa. Hampir semua mahasiswa mempunyai smartphone. Seperti yang telah dijelaskan diatas, bahwa smartphone memiliki beberapa manfaat terutama di kalangan mahasiswa seperti email untuk mengirim dan menerima data perkuliahan, memudahkan mencari bahan referensi dan informasi perkuliahan, kamera dan video untuk mengambil gambar atau 
kejadian yang berhubungan dengan perkuliahan sehingga memudahkan dalam mengerjakan tugas karena dapat dikerjakan juga dalam smartphone tersebut dengan cepat.

Agusta dan Aris (2011) dalam penelitiannya menunjukkan hasil bahwa mahasiswa menggunakan smartphone, diantaranya untuk media sosial dan pemanfaatan multimedia yang tersedia sebagai sarana mencari informasi, sarana belajar dan untuk hiburan. Hasil penelitian juga menyatakan bahwa dengan menggunakan smartphone, ternyata mampu menambah relasi atau hubungan dengan orang lain.

Bentuk, jenis dan merek smartphone atau ponsel pintar semakin berkembang sesuai dengan perkembangan zaman. Salah satunya adalah iPhone produk dari Apple Inc asal Amerika, yang berdasarkan Brand Finance tahun 2015 merupakan perusahaan elektronik dengan profit terbesar di dunia yaitu mencapai $50 \%$ dari penjualan produknya. Publisher (2016) mengatakan bahwa iPhone merupakan ponsel canggih berdesain mewah dan elegan dengan harga selangit mencapai belasan juta rupiah sehingga tidak semua golongan masyarakat dapat memilikinya.

Kesumo dan Rachmawati (2015) dalam penelitiannya mengatakan bahwa brand iPhone dinilai sangat tinggi oleh konsumen iPhone di Indonesia dengan nilai $81,90 \%$. Setiawan (2015) dalam artikelnya menyebutkan bahwa kualitas iPhone memang sangat bagus, berkelas dan bergengsi. Performanya jugas stabil saat digunakan bermain game, memutar video maupun aplikasi dan fitur lain. Belum lagi kamera yang dimiliki iPhone menghasilkan gambar yang sangat jernih dan detil. Namun, secanggih apapun iPhone ternyata memiliki kekurangan disamping kelebihan yang dimiliki.

Pada tahun 2012 dalam laman gopego.com menuliskan bahwa sebuah survey pernah dilakukan terhadap masyarakat Inggris usia dewasa pengguna iPhone. Survey tersebut dilakukan untuk mengetahui ketertarikan mereka dalam membeli iPhone. Dan fakta dari hasil survey tersebut menyatakan bahwa hanya sedikit sekali dari mereka yang puas setelah membeli iPhone. Dari hasil penelitian tersebut tercatat $22 \%$ pengguna iPhone menyesal telah membeli iPhone. Jika dihitung maka persentase itu mewakili 1 dari setiap warga Inggris. Namun sayangnya dalam survey tersebut hanya menyebutkan banyaknya ketidakpuasan pengguna iPhone saja tanpa menyebutkan penyebab lain selain salah satu produk $i$ Phone yaitu $4 S$ yang boros baterai.

Etherington (2012) dalam artikelnya, menuliskan bahwa survey yang dilakukan oleh Perusahaan Riset Konsumen Perangkat Selular kepada 16.000 pengguna iPhone di Amerika, menghasilkan fakta bahwa terjadi penurunan kepuasan pengguna iPhone pada IOS 6. Konsumen lebih menyukai IOS 5 karena fitur yang tersedia mudah dimengerti dibandingkan dengan IOS 6.

Selain hasil survey dari luar negeri, peneliti melakukan observasi di kota Malang pada Oktober 2015 sampai awal 2016 bahwa telah banyak mahasiswa yang menggunakan smartphone sebagai ponsel pilihannya. Kebanyakan dari mereka menggunakan merek iPhone untuk berfoto ataupun untuk memanfaatkan fitur dan aplikasi yang ada. Selanjutnya dilakukan wawancara pada januari 2016 kepada mahasiswi $\mathrm{R}$ (22 tahun) mengenai iPhone yang telah dibelinya. Berdasarkan hasil wawancara, ia merasa kurang puas dengan fitur yang ada pada iPhone. Ia merasa cemas dan ragu terhadap keputusan pembelian yang ia lakukan sendiri dalam 
memilih ponsel kala itu. Karena yang pertama, iPhone tidak memiliki fasilitas Bluetooth yang dapat digunakan untuk mentransfer data ke ponsel selain iPhone sehingga ketika ada data-data penting yang harus segera dikirimkan, ia melakukan pengiriman melalui email. Hal tersebut ternyata sangat merepotkan apabila ia harus menerima data dari ponsel selain iPhone. Sehingga untuk menutupi kekurangan tersebut, $\mathrm{R}$ membeli lagi ponsel lain dengan merek yang berbeda. Berdasarkan hasil yang didapat tersebut, peneliti merasa tertarik untuk menjadikan mahasiswa pengguna iPhone di kota Malang sebagai subjek penelitian.

Pada tahap evaluasi setelah pembelian, apabila konsumen merasakan suatu ketidaknyamanan seperti keraguan karena produk yang dibeli tidak sesuai dengan harapan maka konsumen tersebut mengalami postpurchase dissonance. Tarigan (2013) menyatakan bahwa postpurchase dissonance merupakan bentuk cognitive dissonance dalam kajian pemasaran utamanya mengenai konteks pembelian.

Festinger (dalam Tarigan, 2013) mengatakan cognitive dissonance adalah keadaan psikologis yang dihasilkan saat individu merasakan bahwa kedua pengertian terhadap sesuatu hal yang dipercayainya sebagai suatu kebenaran, tidak sesuai antara satu dengan yang lainnya. Kemudian Festinger (dalam Sweeney, Hausknecht, \& Soutar, 2000) lebih lanjut menjelaskan bahwa cognitive dissonance merupakan suatu keadaan ketidaknyamanan psikologis yang mendorong seseorang untuk mengurangi keraguan (disonansi) atas keputusan yang telah terjadi. Hawkins, Best dan Coney (1998) mendefinisikan bahwa postpurchase dissonance ialah keraguan yang terjadi setelah melakukan keputusan yang sulit dan relatif permanen dalam pembelian barang atau produk. Keraguan tersebut terjadi akibat adanya kesenjangan antara kenyataan dengan apa yang diharapkan konsumen mengenai produk yang telah dibeli.

Saleem, Ali dan Ahmad (2012) dalam penelitiannya terhadap mahasiswa dari beberapa universitas di Twin City (Amerika Serikat) mengungkapkan hasil bahwa mengkonsumsi produk secara hedonis tidak menyebabkan postpurchase dissonance pada konsumen. Sementara postpurchase dissonance terjadi akibat dampak dari pembelian impulsif dan keterlibatan sebuah produk tertentu.

Assael (1984) menjelaskan bahwa akan menjadi suatu kerugian secara finansial bila terjadi postpurchase dissonance. Sementara kerugian yang bersifat psikologis adalah adanya perasaan tidak menyenangkan karena menganggap bahwa keputusan yang diambil dalam pembelian merupakan keputusan yang kurang tepat.

Hawkins, David dan Best (2007) mengatakan bahwa konsumen yang mengalami disonansi pasca pembelian akan berdampak pada perilaku tidak akan melakukan pemakaian, pembuangan produk, perilaku mengeluh, dan tidak melakukan pembelian ulang produk serta merasakan penyesalan pasca pembelian. Hal tersebut juga akan berakibat pada kerugian penjual dikarenakan konsumen yang tidak merasa puas dapat menyebarkan kabar-kabar negatif terkait produk, berhenti membeli, dan memakai produk. Tarigan (2013) mengatakan bahwa disonansi pasca pembelian juga berpengaruh terhadap kepuasan konsumen. Konsumen yang mengalami disonansi tidak akan merasa puas terhadap keputusan pembelian yang dilakukan. Chebab (2010) menambahkan bahwa konsumen yang merasa tidak puas terhadap produk yang dibeli dapat beralih ke produk lain, tidak merekomendasikan produk kepada konsumen lain, dan pengembalian produk kepada penjual. 
Keragu-raguan yang dialami setelah pembelian pasti berbeda-beda antara individu satu dengan individu yang lainnya. Menurut Hawkins, Bes dan Coney (1998), ada beberapa faktor yang dapat mempengaruhi terjadinya postpurchase dissonance. Salah satu faktor yang disebutkan adalah the individual's tendency to experience anxiety. Yang mana beberapa individu memiliki kecenderungan yang berbeda antara yang satu dengan yang lainnya dalam mengalami rasa cemas. Kecemasan ini dapat disebabkan oleh salah satu trait kepribadian yang dimiliki oleh seorang konsumen. Semakin tinggi tingkat kecemasan yang dimiliki oleh seorang individu maka semakin tinggi kemungkinannya mengalami postpurchase dissonance.

Gordon W. W Allport (dalam Jaenudin, 2012) menyatakan bahwa kepribadian merupakan organinasi dinamis (mengalami perubahan namun dalam perubahan tersebut terdapat polapola yang bersifat tetap) dalam diri individu sebagai sistem psikofisik yang menentukan cara yang khas dalam menyesuaikan diri terhadap lingkungannya tersebut. Hawkins, Best dan Coney (1998) menyatakan bahwa kepribadian konsumen dapat memandu langsung perilaku yang dipilih untuk mencapai tujuan dalam situasi yang berbeda-beda. Assael (1984) mengungkapkan bahwa karateristik kepribadian dapat digunakan untuk menggambarkan tentang perilaku konsumen, cara promosi atau pengiklanan, memposisikan suatu produk dan pemilihan media pemasaran.

Berkaitan dengan kepribadian, Sitorus (2007) menggunakan teori kepribadian Jung dan Eysenck mengenai tipe introvert dan ekstrovert untuk meneliti postpurchase dissonance. Dalam penelitian tersebut, ditemukan hasil bahwa terdapat perbedaan postpurchase dissonance antara konsumen yang memiliki kepribadian introvert dan ekstrovert. Hasil penelitian menunjukkan bahwa individu atau konsumen yang memiliki kepribadian introvert terbukti memiliki kecenderungan lebih besar mengalami postpurchase dissonance atas barang atau produk yang telah dibelinya daripada konsumen yang memiliki tipe kepribadian ekstrovert.

Selain tipe kepribadian introvert dan ekstrovert, terdapat tipe kepribadian lain yang dihasilkan dari temuan kerja kelompok antara dua ahli jantung yaitu Friedman dan Rosenman serta seorang ahli biokimia, Myers. Tipe kepribadian tersebut adalah kepribadian tipe A dan tipe B. Friedman dan Rosenman (dalam Munandar, 2012) mengatakan bahwa kedua tipe kepribadian tersebut memiliki pola perilaku yang masing-masing terdiri dari satu perangkat ciri kepribadian yang majemuk. Kedua tipe kepribadian tersebut akan berbeda dalam mengatasi perubahan-perubahan yang terjadi dalam lingkungan mereka nantinya.

Mengingat karaterisktik yang dijelaskan oleh Friedman dan Rosenman (dalam Wijono, 2012) bahwa kepribadian tipe A adalah individu yang kompetitif, agresif, cepat tangkas, tidak sabar sehingga mudah stress, cemas, tertekan dan sulit untuk bersantai, maka kepribadian tipe A diyakini memiliki kecemasan yang tinggi dan tergesagesa dalam mengambil keputusan. Sementara dalam kegiatan perilaku konsumen, dibutuhkan pengambilan keputusan untuk menentukan suatu pilihan. Dalam ciri-cirinya, tipe A dikatakan terlalu cepat dalam mengambil keputusan karena ia tidak suka berlamalama membuang waktu, karena bagi tipe A waktu adalah sesuatu yang sangat berharga. Akibatnya, ia rentan cemas dan stress saat produk yang dipilih ternyata tidak sesuai dengan harapannya saat melakukan evaluasi. Pada kepribadian 
tipe B dijelaskan bahwa ia lebih rileks, tidak menyukai kesulitan, menggunakan waktunya untuk hal yang disukai, tidak mudah iri dan tidak mudah stress. Sehingga individu tipe B tidak mudah mengalami postpurchase dissonance karena memang lebih rileks dalam perilakunya. Oleh karena itu, sangatlah menarik meneliti perbedaan kepribadian tipe A dan B kaitannya dalam postpurchase dissonance.

Sesuai dengan penjelasan yang telah dituliskan di atas bahwa sebelumnya telah ada penelitian tentang perbedaan postpurchase dissonance yang dikaitkan dengan kepribadian, yaitu penelitian oleh Sitorus (2007) yang menggunakan teori kepribadian Jung dan Eysenck mengenai tipe introvert dan ekstrovert. Namun dalam penelitian ini, peneliti menggunakan kepribadian berdasarkan teori Friedman dan Rosenman, yaitu kepribadian tipe A dan tipe B dalam mengungkap perbedaan postpurchase dissonance.

Berdasarkan uraian di atas dapat disimpulkan bahwa individu dengan kepribadian tipe A dan tipe B memiliki perbedaan keraguraguan pasca pembelian atau postpurchase dissonance. Sehingga didapatkan suatu rumusan masalah dalam penelitian ini yaitu apakah ada perbedaan antara kepribadian tipe A dan B dalam mengalami postpurchase dissonance pada mahasiswa pengguna iPhone?. Adapun tujuan dari penelitian yang dilakukan ini adalah untuk mengetahui perbedaan mahasiswa pengguna iPhone dengan kepribadian tipe A dan tipe B dalam mengalami postpurchase dissonance. Manfaat dari hasil penelitian yang dilakukan yaitu dapat digunakan oleh masyarakat khususnya mahasiswa, untuk lebih berhati-hati dan memikirkan keputusan dengan matang dalam membeli ponsel canggih yang berharga dan bernilai tinggi. Manfaat lain juga dapat digunakan produsen atau pemasar agar lebih memenuhi fitur dalam ponsel yang dibutuhkan masyarakat, mengingat konsumen memiliki perbedaan kepribadian yang akan mempengaruhi perilaku konsumennya agar samasama menguntungkan. Sedangkan manfaat teoritis dalam penelitian ini yaitu memberikan referensi dan wawasan dalam ranah ilmu Psikologi kaitannya dengan perilaku konsumen.

Sebelum membahas mengenai postpurchase dissonance, terlebih dahulu perlu dipahami kajian mengenai disonansi kognitif (cognitive dissonance). Menurut Tarigan (2013), teori cognitive dissonance ini dikembangkan oleh Psikolog Sosial Leon Festinger pada tahun 1957. Festinger (dalam Tarigan, 2013) mendefinisikan bahwa cognitive dissonance adalah keadaan psikologis yang dihasilkan saat individu merasakan bahwa kedua pengertian terhadap sesuatu hal yang dipercayainya sebagai suatu kebenaran, tidak sesuai antara satu dengan yang lainnya. Ketidaknyaman secara psikologis tersebut, memotivasi individu untuk megurangi keraguraguan atas keputusan yang ia buat.

Apabila cognitive dissonance terjadi setelah melakukan suatu pembelian suatu barang atau produk tertentu, maka hal tersebut menurut Schiffman dan Kanuk (1994) dinamakan postpurchase dissonance. Assael (1984) menyatakan bahwa postpurchase dissonance merupakan keadaan ketidaknyamanan psikologis berupa keraguan yang berasal dari dua kepercayaan yang berbeda terhadap produk yang telah dibeli. Keraguan pasca pembelian ini terjadi ketika seseorang memutuskan untuk membeli sebuah merek dari berbagai merek dalam kategori produk yang sama. Loudon dan Bitta (dalam Haryanti dan Ginting, 2013) berpendapat bahwa postpurchase dissonance 
terjadi akibat perbedaan antara keputusan konsumen dengan evaluasi sebelumnya terhadap produk tertentu.

Hawkins, Best dan Coney (1998) mendefinisikan bahwa postpurchase dissonance ialah keraguan yang terjadi setelah melakukan keputusan yang sulit dan relatif permanen dalam pembelian barang atau produk. Kemudian pada tahap ini individu tersebut mencari penguatan atas keputusan pembelian yang ia lakukan. Penguatan yang dimaksud adalah dengan mencari informasi tambahan mengenai produk yang ia beli tersebut.

Hawkins, Best dan Coney (1998) membuat penjelasan mengenai perilaku konsumen mulai dari pembelian produk, hingga beberapa pembelian diikuti dengan postpurchase dissonance. Postpurchase dissonance terjadi karena konsumen meragukan kebijakan pembelian yang telah dilakukan. Dalam kondisi postpurchase dissonance, ada dua hal yang dilakukan oleh seorang konsumen, yaitu pembelian diikuti nonuse (mengembalikan atau menyimpan produk tersebut tanpa menggunakannya) atau pembelian yang berakhir dengan penggunaan produk, meskipun sebelumnya telah terjadi postpurchase dissonance. Hal tersebut berkaitan dengan kepuasan konsumen. Ketika konsumen merasa tidak puas atas produk yang dibeli maka akan menimbulkan komplain. Sebaliknya, apabila konsumen merasa puas (satisfaction) dengan produk yang dibeli maka dapat memberikan peningkatan dan pengulangan pembelian terhadap produk tersebut.

Sweeney, Hausknecht dan Soutar (2000) mengemukakan 3 dimensi yang dapat digunakan untuk mengukur postpurchase dissonance, yaitu:

1. Emotional (Emosi)

Emosional yang dimaksud adalah ketidaknyamanan psikologis yang merupakan konsekuensi atas keputusan pembelian terhadap suatu produk. Keadaan tidak nyaman secara psikologis setelah pembelian tersebut dapat dikatakan bahwa individu mengalami postpurchase dissonance.

2. Wisdom of Purchase

(Kebijaksanaan Pembelian) Merupakan kesadaran individu setelah pembelian, apakah telah membeli produk yang tepat atau bahkan mungkin tidak membutuhkan produk tersebut. Setelah proses pembelian, individu dihadapkan pertanyaan seputar keputusan membeli yang telah dia lakukan. Apabila individu merasa bahwa keputusan pembelian yang dia lakukan adalah benar, dimana produk yang telah dibeli adalah tepat dan berguna, maka individu cenderung tidak akan mengalami postpurchase dissonance.

3. Concern Over Deal

(Kekhawatiran Atas Kesepakatan Pembelian) Merupakan kesadaran individu setelah proses pembelian yang telah dilakukan, apakah mereka telah dipengaruhi oleh agen penjual (sales staff) terhadap keyakinan mereka sendiri atas produk yang dibeli. Individu yang melakukan keputusan membeli atas dasar pertimbangan diri sendiri (individu merasa bebas dalam memutuskan pembelian terhadap suatu produk) akan dihadapkan pada informasiinformasi dari luar diri individu tersebut yang dapat membuat individu mengalami postpurchase dissonance. 
Hawkins, Best dan Coney (1998) menjelaskan bahwa ada beberapa faktor yang dapat mempengaruhi postpurchase dissonance, antara lain yaitu:

1. The degree of commitment or irrevocability of the decision

Semakin mudah mengubah keputusan, semakin rendah kemungkinan seorang mengalami kebingungan (dissonance). Hal ini dapat terjadi pada saat membeli suatu produk yang memiliki banyak alternatif lainnya dimana masingmasing alternatif memiliki kelebihan ataupun kekurangan yang relatif sama.

2. The importance of the decision to the consumer

Semakin penting keputusan tersebut bagi konsumen, semakin besar kemungkinannya mengalami dissonance. Keputusan seperti ini akan membuat seorang konsumen memikirkan secara matang produk yang hendak dibeli sebelum melakukan pembelian. Oleh karena itu keputusan yang salah dalam membeli suatu produk akan mengarah kepada postpurchase dissonance yang akan dialami oleh konsumen tersebut.

3. The difficulty of choosing among the alternatives

Semakin sulit memilih alternatif, semakin tinggi kemungkinan seorang konsumen mengalami dissonance. Hal ini dikarenakan alternatif yang ada tidak menawarkan kelebihankelebihan lainnya yang tidak ada pada produk yang hendak dipilih. Atau dengan kata lain alternatif yang ada tidak dapat menutupi kekurangan yang ada pada produk yang hendak dibeli.

4. The individual's tendency to experience anxiety

Beberapa individu memiliki tingkatan atau kecenderungan yang berbeda antara yang satu dengan yang lainnya dalam mengalami rasa cemas. Kecemasan ini dapat disebabkan oleh salah satu trait kepribadian yang dimiliki oleh seorang konsumen. Semakin tinggi tingkat kecemasan yang dimiliki oleh seorang individu maka semakin tinggi kemungkinannya mengalami postpurchase dissonance.

Alwisol (2006) menjelaskan bahwa kepribadian merupakan terjemahan dari bahasa Inggris personality. Sementara personality sendiri berasal dari dari bahasa Yunani kuno prosopon atau persona yang berarti "topeng" yang biasa dipakai artis dalam pertunjukan teater. Para artis tersebut bertingkah laku sesuai dengan ekspresi topeng yang dipakainya tersebut seolah mewakikili ciri kepribadian tertentu. Jadi dahulu kala konsep awal pada masyarakat awam mengartikan personality merupakan tingkah laku yang ditampakkan ke lingkungan sosial. Kemudian istilah tersebut berkembang menjadi istilah personality secara ilmiah.

Setiap individu yang terlahir memiliki tipe dan ciri kepribadian yang berbeda antara satu dengan yang lainnya. Allport (dalam Jaenudin, 2012) menyatakan bahwa kepribadian merupakan organinasi dinamis (mengalami perubahan namun dalam perubahan tersebut terdapat polapola yang bersifat tetap) dalam diri individu sebagai sistem psikofisik yang menentukan cara yang khas dalam menyesuaikan diri terhadap lingkungannya tersebut.

Rice (dalam Pernando, 2010) mengungkapkan bahwa penemu konsep pola perilaku kepribadian tipe A dan B berasal dari kerja kelompok antara dua ahli jantung 
yaitu Friedman dan Rosenman, dan seorang ahli biokimia, Myers. Kemudian Friedman \& Rosenman (dalam Wijono, 2012) telah mengelompokkan kepribadian dalam 2 tipe kepribadian yang berbeda, yaitu kepribadian tipe A dan kepribadian tipe B. Friedman dan Rosenman (dalam Munandar, 2012) mengatakan bahwa kedua tipe kepribadian tersebut memiliki pola perilaku yang masingmasing terdiri dari satu perangkat ciri kepribadian yang majemuk. Kedua tipe kepribadian tersebut akan berbeda dalam mengatasi erubahan-perubahan yang terjadi dalam lingkungan mereka.

Ada individu yang memiliki ciri cepat dalam mengerjakan tugas, mempunyai sikap kompetitif tinggi, tidak sabar degan cara apapun untuk mencapai tujuan yang diinginkannya atau menyelesaikan tugas kurang dari waktu yang ditentukan, berorientasi pada prestasi, ambisius, agresif, mudah stress, mudah tertekan, tergesagesa, mudah gelisah, sering mengalami ketegangan, dan berbicara dengan penuh semangat. Individu yang demikian merupakan individu dengan kepribadian tipe A, yang disebutkan Friedman dan Schustack (2008) merupakan kepribadian yang kecanduan kerja (workaholic personality). Schultz dan Schultz (2006) menyebutkan bahwa ada 2 karateristik utama pada individu berkperibadian tipe A yaitu kompetitif dan merasa waktu selalu mendesak. Sebaliknya, kepribadian tipe B mempunyai pembawaan lebih rileks, tidak suka kesulitan, jarang marah, menggunakan banyak waktunya untuk kegiatan yang disenangi, tidak mudah stress, tidak mudah iri, bekerja terus menerus, jarang kekurangan waktu, dan berbicara dengan nada suara pelan dan bergeraknya lamban.

Friedman dan Rosenman (dalam Wijono, 2012) menuliskan secara rinci perbedaan kedua tipe kepribadian tersebut pada tabel di bawah ini:

Tabel 1. Perbedaan Tipe Kepribadian

\begin{tabular}{ll}
\hline \multicolumn{1}{c}{ Kepribadian Tipe A } & \multicolumn{1}{c}{ Kepribadian Tipe B } \\
\hline Kompetitif & Rileks (santai) \\
Berorientasi pada prestasi & Tidak menyukai kesulitan \\
Agresif & Jarang marah \\
Cepat/tangkas & Menggunakan banyak waktunya untuk \\
& kegiatan-kegiatan yang disenangi \\
Mudah stress & Tidak mudah stress \\
Tidak sabar & Tidak mudah iri \\
Mudah gelisah & Bekerja terus menerus \\
Selalu siap siaga (waspada) & Jarang kekurangan waktu \\
Berbicara dengan semangat & Bergerak dan berbicara pelan \\
\hline
\end{tabular}

Berdasarkan dari uraian teori diatas, maka dapat disimpulkan bahwa kepribadian tipe A merupakan kepribadian dengan ciri kompetitif untuk berprestasi, ambisius, cepat dan tergesagesa dalam melakukan sesuatu karena memandang bahwa waktu begitu sangat berharga sehingga mudah stres, cemas, tertekan dan tegang karena sulit untuk bersantai. Sedangkan kepribadian tipe B memiliki karateristik tidak menyukai kesulitan atas yang dijalani, jarang marah dan santai sehingga lebih banyak menggunakan waktunya untuk hal yang disenangi, tidak mudah iri terhadap 
pencapaian orang lain namun dapat bekerja terus sesuai kemampuan. Dengan karateristik yang demikian sehingga tipe B tidak mudah merasa stress atau tertekan.

Adapun aspek-aspek yang terdapat dalam kepribadian tipe A dan tipe B menurut Chesney, Eagleston, dan Rosenman (1980) antara lain: (1) gaya bicara, (2) respon menjadi pembicara(interviewer), (3) perilaku, (4) typical content.

Aspek-aspek tersebut tentunya memiliki karateristik yang berbeda pada masingmasing kepribadian tipe A dan tipe B, berikut adalah kategorinya berdasarkan Chesney, Eagleston, dan Rosenman (dalam Feldman, 1985) :

1. Kepribadian Tipe A

a. Gaya bicara: cepat, semangat, menguasai pembicaraan, cepat dalam mengakhirinya, volume suara keras, segera menjawab, memberi tekananpada kata-kata kunci, meledakmeledak, statemennya pendek, tepat dan keras.

b. Respon jadi pembicara: cenderung menunjukkan permusuhan dalam pembicaraan yang ditunjukkan dengan merasa bosan dan otoriter, bersaing untuk menguasai pembicaraan, terburu-buru, jarang melakukan humor, sering berusaha untuk menyelesaikan pertanyaan orang lain dan sering menyela pembicaraan.

c. Perilaku: suka mengeluh, tegang, siap siaga, sering mengepalkan tangan, senyumnya datar dan tertawa keras.

d. Typical content (dalam hal kepuasan): merasa tidak puas dalam bekerja sehingga berorientasi untuk bekerja terus menerus, tidak puas dengan satu pekerjaan, bekerja keras, ambisius, memandang waktu merupakan hal yang penting, tidak sabaran untuk menunggu, suka bersaing dan menunjukkan sikap permusuhan dalam berbagai hal seperti; memberikan argumen, menetapkan standart kualifikasi yang berlebihan dan menunjukkan sikap gerak isyarat yang kurang pantas.

2. Kepribadian Tipe B

a. Gaya bicara: cenderung lambat, tidak segera menjawab, volume suara pelan, dan senang mengkhayal sehingga ada frekuensi untuk memberi jeda saat berbicara.

b. Respon jadi pembicara: jarang terburuburu, menyukai humor, tidak menunjukkan sikap bermusuhan seperti; tidak bosan, tidak menunjukkan penolakan atau rasa keberatan. Ia juga jarang menyela pembicaraan, jarang menyelesaikan pertanyaan orang lain, jarang bersaing untuk menguasai pembicaraan.

c. Perilaku: tenang, jarang mengeluh, santai, tenang, menyenangkan, penuh perhatian dan bersahabat, memiliki senyum lebar, memiliki tawa yang kecil.

d. Typical cotent (dalam hal kepuasan): merasa puas dengan pekerjaan atau satu pekerjaan, tidak terlalu bekerja keras, tidak ambisius atau bersaing, lebih suka mengerjakan aktivitas satu persatu, sabar dan tidak mudah marah dalam hal yang menjengkelkan, tidak menunjukkan sikap permusuhan dengan rekan kerjanya, jarang memberi argumen, tidak menetapkan standrat kualifikasi yang berlebihan.

Allport (dalam Jaenudin, 2012) menyatakan bahwa kepribadian merupakan organinasi dinamis (mengalami perubahan namun dalam perubahan tersebut terdapat 
polapola yang bersifat tetap) dalam diri individu sebagai sistem psikofisik yang menentukan cara yang khas dalam menyesuaikan diri terhadap lingkungan. Friedman dan Rosenman serta seorang ahli biokimia Myers mengemukakan teori tipe kepribadian yang masingmasing terdiri dari satu perangkat ciri kepribadian majemuk. Friedman dan Rosenman (dalam Munandar, 2012) mengatakan bahwa kedua tipe kepribadian tersebut akan berbeda dalam mengatasi perubahanperubahan yang terjadi dalam lingkungan mereka. Tipe kepribadian tersebut adalah kepribadian tipe A dan tipe B.

Friedman dan Rosenman (dalam Wijono, 2012) mengatakan bahwa kepribadian tipe A adalah individu yang kompetitif, agresif, cepat tangkas, tidak sabar sehingga mudah stress, cemas, tertekan dan sulit untuk bersantai, maka kepribadian tipe A diyakini memiliki kecemasan yang tinggi dan tergesa-gesa dalam mengambil keputusan. Dalam kegiatan perilaku konsumen dibutuhkan pengambilan keputusan. Sementara tipe A terlalu cepat dalam menentukan pilihan karena ia tidak suka berlamalama membuang waktu, karena bagi tipe A waktu adalah sesuatu yang sangat berharga. Akibatnya, ia rentan cemas dan stress saat produk yang dipilih ternyata tidak sesuai dengan harapannya ketika melakukan evaluasi. Sehingga menimbulkan postpurchase dissonance tinggi. Kemudian ia merasa bahwa ternyata produk yang dibelinya tidak tepat atau tidak berguna serta merasa menyesal telah mendengarkan bujukan orang lain dalam membeli suatu produk.

Pada kepribadian tipe B, Friedman dan Rosenman (dalam Wijono, 2012) menjelaskan bahwa ia lebih rileks, tidak menyukai kesulitan, menggunakan waktunya untuk hal yang disukai, tidak mudah iri dan tidak mudah stres. Sehingga individu tipe B tidak mudah mengalami postpurchase dissonance karena memang lebih rileks dalam perilakunya. Sehingga ketidaknyamanan psikologisnya dalam pembelian tidak tinggi jika ada hal yang kurang dari produk yang dibelinya dan cenderung merasa bahwa produk yang ia beli tetap berguna.

Untuk memenuhi kebutuhan hidup, manusia melakukan kegiatan yang berkaitan dengan perilaku konsumen. Engel, Blackwell dan Miniard (1994) mengatakan bahwa tindakan yang langsung terlibat dalam mendapatkan, mengkonsumsi, menghabiskan produk dan jasa, termasuk di dalamnya proses keputusan yang mendahului dan menyusuli tindakan tersebut merupakan kegiatan perilaku konsumen. Assael (1984) mengatakan bahwa dalam perilaku konsumen, tedapat 5 tahap proses pembelian suatu produk yaitu: (1) tahap pengenalan kebutuhan (need arousal), (2) tahap pencarian informasi (consumer information processing), (3) tahap evaluasi produk (brand evaluation), (4) pembelian (purchase), (5) evaluasi setelah pembelian (postpurchase evaluation).

Pada tahap kelima, individu atau konsumen melakukan evaluasi terhadap produk yang dibeli. Apabila ia merasa puas, maka ada kemungkinan untuk dia mengulang pembelian di kemudian hari, begitu pula sebaliknya. Apabila konsumen merasakan suatu ketidaknyamanan seperti keraguan karena produk yang dibeli tidak sesuai dengan harapan maka konsumen tersebut mengalami postpurchase dissonance. Tarigan (2013) menyatakan bahwa postpurchase dissonance merupakan bentuk cognitive dissonance (teori psikologi sosial) dalam kajian pemasaran utamanya mengenai konteks pembelian. 
Keragu-raguan atau kecemasan yang dialami setelah pembelian pasti berbedabeda antara individu satu dengan individu yang lainnya. Menurut Hawkins, Best dan Coney (1998), ada beberapa faktor yang dapat mempengaruhi terjadinya postpurchase dissonance. Salah satu faktor yang disebutkan adalah the individual's tendency to experience anxiety. Yang mana beberapa individu memiliki tingkatan atau kecenderungan yang berbeda antara satu dengan yang lainnya dalam mengalami rasa cemas. Kecemasan ini dapat disebabkan oleh salah satu trait kepribadian yang dimiliki oleh seorang konsumen.

Berdasarkan uraian di atas dapat dikatakan bahwa individu dengan kepribadian tipe A dan tipe B mempunyai perbedaan dalam mengalami keraguraguan pasca pembelian atau postpurchase dissonance. Sehingga didapatkan hipotesis dalam penelitian ini yaitu ada perbedaan postpurchase dissonance pada mahasiswa pengguna iPhone dengan kepribadian tipe A dan tipe B.

\section{METODE}

Dalam penelitian ini, peneliti menggunakan pendekatan kuantitatif dengan menggunakan jenis komparatif. Azwar (2014) menjelaskan bahwa penelitian kuantitatif adalah penelitian dengan sampel besar yang menekankan analisis pada datadata numerical (angka), kemudian diolah dengan menggunakan metode statistika sehingga diperoleh signifikansi perbedaan kelompok atau signifikansi hubungan antar variabel yang diteliti. Sementara penelitian komparatif adalah penelitian yang bersifat membandingkan untuk melihat perbedaan antara satu kelompok dengan kelompok lainnya. Sugiyono (2007) juga menjelaskan bahwa penelitian komparatif yaitu penelitian yang membandingkan keadaan suatu variabel dari dua sampel atau lebih. Dalam penelitian ini, peneliti ingin membedakan antara variabel kepribadian tipe A dan tipe B terhadap variabel postpurchase dissonance.

Populasi dalam penelitian ini adalah mahasiswa aktif Universitas Muhammadiyah Malang yang menggunakan iPhone. Penelitian ini akan menyelidiki tentang perbedaan postpurchase dissonance ditinjau dari kepribadian tipe A dan tipe B pada mahasiswa pengguna iPhone. Karateristik subjek dalam penelitian ini adalah mahasiswa laki-laki maupun perempuan dan memiliki atau pernah memiliki iPhone. Teknik pengambilan sampel menggunakan non probability sampling. Menurut Sugiyono (2007) non probability sampling yaitu teknik pengambilan sampel yang tidak memberikan peluang yang sama bagi setiap anggota populasi untuk dipilih menjadi anggota sampel. Sementara teknik yang dipakai adalah purposive sampling. Karena menurut Winarsunu (2009) sampel yang akan diteliti sudah ditentukan karateristiknya dan diketahui lebih dulu berdasarkan ciri dan sifat populasinya. Jumlah sampel dalam penelitian ini sebanyak 125 subjek, dengan pertimbangan peneliti bahwa menurut Gay dan Diehl (1992) ketentuan penelitian kausal komparatif jumlah sampel yang diambil adalah minimal 30 sampel per group.

Pada penelitian ini terdapat dua variabel, yaitu variabel bebas $(X)$ / independent variable dan variabel terikat $(\mathrm{Y}) /$ dependent variable. Adapun yang menjadi variabel bebas $(X)$ / independent variable adalah kepribadian tipe A dan tipe B. Kepribadian tipe A merupakan kepribadian dengan ciri kompetitif untuk berprestasi, ambisius, cepat dan tergesagesa dalam melakukan sesuatu karena memandang bahwa waktu begitu 
sangat berharga sehingga mudah stress, cemas, tertekan dan tegang karena sulit untuk bersantai. Sedangkan kepribadian tipe B memiliki karateristik tidak menyukai kesulitan atas yang dijalani, jarang marah dan santai sehingga lebih banyak menggunakan waktunya untuk hal yang disenangi, tidak mudah iri terhadap pencapaian orang lain namun dapat berusaha terus sesuai kemampuan. Dengan karateristik yang demikian sehingga tipe B tidak mudah merasa stress atau tertekan. Adapun aspekaspek yang terdapat dalam kepribadian tipa A dan B menurut Chesney, Eagleston, dan Rosenman (1980) antara lain: (1) gaya bicara, (2) respon menjadi pembicara (interviewer), (3) perilaku, (4) typical content (dalam hal kepuasan). Alat ukur skala yang digunakan dalam penelitian ini mengadaptasi dari penelitian Hendarto (2014) dengan total item yang berjumlah 47 Item. Jenis skala yang digunakan adalah skala Guttman, yaitu pernyataan yang disajikan dengan jawaban "YaTidak" yang bertujuan untuk mendapatkan jawaban yang tegas dari subjek dalam mengungkapkan variabel kepribadian tipa A dan tipe B. Skala pengukuran ini dibuat bervariasi antara pernyataan yang bersifat favourable dan yang bersifat unfavourable, hal ini bertujuan untuk menghindari streotipe jawaban dari subjek. Pernyataan favourable adalah pernyataan yang memihak pada objek penelitian, sedangkan pernyataan unfavourable adalah pernyataan yang tidak mendukung atau tidak memihak pada objek penelitian. Hasil jawaban subjek diberikan skor "1" untuk jawaban "Ya" dan skor "0" untuk jawaban "Tidak". Kemudian hasil uji coba skala Kepribadian Tipe A dan B menunjukkan dari 47 item, terdapat 14 item gugur sehingga tersisa 33 item valid dengan indeks validitas 0,338 0,921 dan memiliki nilai reliabilitas sebesar 0,985.

Adapun variabel terikat $(\mathrm{Y})$ / dependent variable dalam penelitian ini adalah postpurchase dissonance. Postpurchase dissonance merupakan ketidaknyamanan psikologis berupa keraguraguan akibat kepercayaan yang berbeda antara keputusan yang diambil dengan evaluasi sebelumnya pada produk tertentu yang telah dibeli. Kemudian pada tahap ini individu akan mencari penguatan atas keputusan pembelian yang ia lakukan. Penguatan yang dimaksud adalah dengan mencari informasi tambahan mengenai produk yang ia beli tersebut. Terdapat 3 dimensi yang dapat digunakan untuk mengukur adanya postpurchase dissonance menurut Sweeney, Hausknecht dan Soutar (2000). Ketiga dimensi itu antara lain adalah emotional, wisdom of purchase dan concern over deal. Skala penelitian ini mengadaptasi dari skala Sweeney, Hausknecht dan Soutar (2000) dengan total item yang berjumlah 22 item dan disajikan dalam bentuk favourable. Jenis skala yang digunakan adalah skala Likert yang telah disusun menjadi empat alternativ jawaban yaitu: sangat setuju (SS), setuju (S), tidak setuju (TS) dan sangat tidak setuju (STS). Penilaian dari skala ini adalah bergerak dari angka 4 sampai 1 untuk pernyataan favourable. Sehingga penilaian $S S=4, S=3, T S=2$, STS=1. Jawaban netral sengaja ditiadakan karena untuk menghindari kecenderungan subjek memberi jawaban netral atau raguragu dalam memilih pernyataan yang telah disediakan oleh peneliti. Kemudian hasil uji coba skala postpurchase dissonance menunjukkan tidak ada item yang gugur dan memiliki indeks validitas 0,513 0,868 serta memiliki nilai reliabilitas sebesar 0,956.

\section{HASIL}


Penelitian ini dilakukan kepada 125 subjek mahasiswa Universitas Muhammadiyah Malang yang menggunakan iPhone. Adapun rincian hasil dari penelitian tersebut dapat dilihat pada tabel berikut ini:

Tabel 2. Deskripsi Subjek Penelitian

\begin{tabular}{lcc}
\hline \multicolumn{1}{c}{ Kategori } & Jumlah & Persentase \\
\hline Jenis Kelamin & & \\
Laki-laki & 50 & $40 \%$ \\
Perempuan & 75 & $60 \%$ \\
\hline Semester & & \\
$1-4$ & 64 & $51,2 \%$ \\
$5-8$ & 38 & $38,4 \%$ \\
$9-13$ & 23 & $18,4 \%$ \\
\hline Usia (Tahun) & & \\
$17-20$ & 73 & $58,4 \%$ \\
2124 & 46 & $36,8 \%$ \\
$25-28$ & 6 & $4,8 \%$ \\
\hline Fakultas & & \\
FPP & 5 & $4 \%$ \\
FEB & 7 & $5,6 \%$ \\
FAI & 1 & $0,8 \%$ \\
FIKES & 4 & $3,2 \%$ \\
FISIP & 33 & $26,4 \%$ \\
HUKUM & 16 & $12,8 \%$ \\
PSIKOLOGI & 40 & $32 \%$ \\
FKIP & 11 & $8,8 \%$ \\
TEKNIK & 8 & $6,4 \%$ \\
\hline
\end{tabular}

Pada tabel tersebut menjelaskan beberapa kategori dari subjek penelitian. Kategori tersebut meliputi jenis kelamin yang didominasi oleh perempuan (60\%). Hasil penelitian juga menunjukkan bahwa mayoritas subjek penelitian berada pada semester 1 hingga 4 (51,2\%). Kemudian kategori usia didominisasi oleh mahasiswa yang mempunyai rentang usia antara 17 tahun hingga 20 tahun (58,4\%). Dan pada kategori fakultas, didominisasi oleh subjek yang berasal dari fakultas Psikologi (32\%).

Tabel 3. Kategorisasi Variabel

\begin{tabular}{lccc}
\hline \multicolumn{1}{c}{ Variabel } & Interval & Frekuensi & Persentase \\
\hline $\begin{array}{l}\text { Postpurchase Dissonance } \\
\text { Rendah }\end{array}$ & $22-38$ & 57 & $45,6 \%$ \\
Sedang & $39-60$ & 65 & $52 \%$ \\
Tinggi & $61-66$ & 3 & $2,4 \%$ \\
\hline Kepribadian Tipe A & & 54 & \\
Rendah & $22-38$ & 23 & $42,6 \%$ \\
Sedang & $39-60$ & 28 & $51,9 \%$
\end{tabular}




\begin{tabular}{lccc} 
Tinggi & $61-66$ & 3 & $5,6 \%$ \\
\hline Kepribadian Tipe B & & 71 & \\
Rendah & $22-38$ & 34 & $47,9 \%$ \\
Sedang & $39-60$ & 37 & $45,6 \%$ \\
Tinggi & $61-66$ & - & $52 \%$ \\
\hline
\end{tabular}

Berdasarkan tabel di atas, dapat dilihat bahwa hasil penelitian didominasi oleh subjek yang memiliki postpurchase disoonance dengan kategori sedang, yaitu sejumlah 65 subjek dengan persentase $52 \%$. Hasil penelitian juga menunjukkan bahwa terdapat 54 subjek yang memiliki kepribadian tipe A dengan persentase 43,2\%. Pada kepribadian tipe A ini, didominasi oleh kategori postpurchase dissonance sedang, dengan frekuensi 28 (51,9\%). Sementara terdapat 71 subjek yang termasuk dalam kepribadian tipe B dengan persentase 56,8\%. Pada tipe kepribadian B didominasi oleh kategori postpurchase dissonance sedang, dengan frekuensi 52,1\% dan tidak ada subjek kepribadian tipe B yang masuk dalam kategori tinggi.

Dalam uji normalitas ini peneliti menggunakan uji Kolmogorov Smirnov melalui IMB SPSS 18. Setelah pengujian, diperoleh hasil probabilitas sebesar 0,092 untuk postpurchase dissonance dan 0,154 untuk tipe kepribadian. Hasil tersebut lebih besar dari taraf signifikansi 0,05, sehingga dapat dikatakan bahwa data yang diperoleh berdistribusi normal (Siegel, 1994). Dengan demikian, maka dapat disimpulkan bahwa data yang diperoleh dari penelitian ini mewakili populasi. Selain itu dengan mengetahui bahwa distribusi data penelitian bersifat normal, maka uji hipotesa penelitian dapat menggunakan analisis statistik independent sample ttest, dimana salah satu syarat uji independent sample ttest adalah data harus berdistribusi normal.

Tabel 4. Uji ttest Postpurchase Dissonance Berdasarkan Tipe A dan Tipe B

\begin{tabular}{cccccc}
\hline Kepribadian & $\mathbf{N}$ & Mean & Std.Deviation & $\mathbf{t}$ & $\mathbf{p}$ \\
\hline Tipe A & 54 & 38,61 & 11,671 & 0,934 & 0,352 \\
Tipe B & 71 & 36,85 & 9,473 & - & - \\
\hline
\end{tabular}

Berdasarkan analisis uji ttest yang dilakukan, diperoleh hasil yang tertera pada tabel yaitu nilai t sebesar 0,934 dengan signifikansi (p) 0,352. Yang mana 0,352>0,05. Sehingga menunjukkan bahwa tidak ada perbedaan yang signifikan mengenai postpurchase dissonance pada mahasiswa pengguna iPhone dengan kepribadian tipe A dan kepribadian tipe B.

\section{DISKUSI}

Penelitian ini mencoba menguji perbedaan postpurchase dissonance ditinjau dari kepribadian tipe A dan tipe B pada mahasiswa pengguna iPhone. Berdasarkan hasil dalam penelitian ini menunjukkan nilai $\mathrm{t}$ hitung 0,934 dengan signifikansi (p) sebesar 0,352 yang lebih besar dari 0,05 (0,352 > 0,05). Oleh karena itu dapat disimpulkan bahwa hasil penelitian ini menolak hipotesis yang telah peneliti ajukan, yaitu ada perbedaan postpurchase dissonance pada mahasiswa pengguna iPhone dengan kepribadian tipe A dan tipe B. Sehingga didapatkan hasil penelitian bahwa tidak ada 
perbedaan yang signifikan mengenai postpurchase dissonance pada mahasiswa pengguna iPhone ditinjau dari kepribadian tipe A dan B.

Friedman dan Rosenman (dalam Wijono, 2012) mengatakan bahwa kepribadian tipe A adalah tipe yang kompetitif, agresif, cepat tangkas, tidak sabar, mudah stress, mudah tertekan, mudah cemas, dan sulit untuk bersantai. Maka kepribadian tipe A diyakini memiliki kecemasan yang tinggi dan tergesa-gesa dalam mengambil keputusan, termasuk dalam hal pembelian. Karena bagi tipe A, waktu merupakan hal yang sangat berharga sehingga tidak suka berlamalama membuang waktu. Oleh karena itu dalam pembelian, tipe A sangat rentan mengalami postpurchase dissonance. Sedangkan tipe B, merupakan tipe yang lebih rileks, menggunakan waktunya untuk hal yang disukai, tidak mudah iri, tidak mudah stress dan tidak menyukai kesulitan. Dalam proses pembelian, individu tipe B memang lebih rileks dalam perilakunya. Namun ia merupakan kepribadian dengan salah satu ciri tidak menyukai kesulitan, menurut Friedman dan Rosenman (dalam Wijono, 2012). Sehingga dalam pengambilan keputusan memilih produk, kemungkinan tipe B segera memutuskan karena tidak mau berlamalama atau menyulitkan keputusannya sendiri. Sedangkan pengambilan keputusan yang tepat memerlukan pemikiran yang matang. Oleh karena itu, tidak menutup kemungkinan juga bahwa individu dengan kepribadian tipe B mengalami postpurchase dissonance.

Penelitian yang dilakukan oleh Holloway (dalam Tarigan, 2013) menemukan berbagai faktor yang dapat menyebabkan postpurchase dissonance. Salah satu faktor tersebut adalah munculnya hal negatif dari produk yang menjadi pilihan utama. Mengingat apa yang telah dikatakan Friedman dan Rosenman (dalam Wijono, 2012) bahwa tipe A mudah stres, mudah cemas, mudah tertekan dan sulit untuk bersantai, maka ketika hal negatif dari produk yang menjadi pilihan utama muncul, tipe A akan mengalami postpurchase dissonance. Lalu untuk kepribadian tipe B dijelaskan bahwa ia memang lebih rileks, tidak menyukai kesulitan, menggunakan waktunya untuk hal yang disukai, tidak mudah iri dan stress. Namun apabila saat evaluasi ternyata muncul hal negatif dari produk yang dipilih, maka tidak menutup kemungkinan individu tipe B ini juga dapat mengalami postpurchase dissonance, meskipun tidak dalam kadar yang tinggi. Karena pada salah satu aspek kepribadian tipe A dan tipe B menurut Chesney, Egleston, dan Rosenman (dalam Feldman, 1985) terdapat aspek typical content yang membahas mengenai hal kepuasan. Yang mana typical cotent pada kepribadian tipe B ini memiliki beberapa karateristik, di antaranya adalah tipe B akan sabar dan tidak mudah marah dalam hal yang menjengkelkan serta tidak menetapkan standar kualifikasi yang berlebihan.

Dalam penelitiannya di New Delhi, Hasan dan Nasreen (2012) menemukan halhal yang dapat mempengaruhi tingkat postpurchase dissonance dalam perilaku konsumen. Antara lain: (1) keluarga dan teman sebaya, (2) kepribadian konsumen: konsumen yang memiliki kepercayaan diri yang kuat terhadap produk yang dipilihnya, akan mengalami postpurchase dissonance yang lebih rendah bila dibandingkan dengan konsumen yang merasa bingung saat memilih produk, (3) tingkat kepentingan suatu produk.

Gautam (2015) dalam penelitiannya yang berjudul Cognitive Dissonance: Dissonant Buying Behaviour of Consumer towards Cell Phones menemukan hasil penelitian bahwa 
pembelian ponsel bermerek tinggi, akan membuat pelanggan banyak mengalami postpurchase dissonance dibandingkan dengan pembelian ponsel yang bermerek rendah. Sementara Kesumo dan Rachmawati (2015) dalam penelitiannya mengatakan bahwa brand iPhone dinilai sangat tinggi oleh konsumen iPhone di Indonesia dengan nilai $81,90 \%$.

Wicaksono, Suharyono dan Pangestuti (2018) dalam survey yang dilakukan pada pengguna iPhone di Indocell Malang menemukan hasil dalam penelitiannya tersebut bahwa International Brand Image dan Lifestyle berpengaruh signifikan terhadap keputusan pembelian. Brand dianggap penting guna menunjang gaya hidup (lifestyle) untuk menentukan status sosial dari seorang individu, dimana gaya hidup berhubungan dengan tindakan nyata dan pembelian yang dilakukan konsumen pada suatu brand. Jika dihubungkan dengan pembahasan sebelumnya, itu artinya siapa saja entah individu dengan kepribadian tipe A maupun tipe B tentunya memiliki peluang yang sama dalam membeli iPhone ketika mereka memiliki keinginan dan kemampuan finansial yang sesuai, apalagi seorang konsumen dapat membeli sebuah produk (iPhone) tidak harus baru (produk second). Ini artinya, iPhone bisa dibeli dengan harga yang lebih terjangkau bila dibandingkan dengan membeli iPhone yang baru.

Rahmalia (2017) dalam penelitiannya menyebutkan bahwa tidak terdapat perbedaan postpurchase dissonance antara lakilaki dan perempuan, namun terdapat hubungan antara shopping lifestyle tipe hedonic consumers dengan postpurchase dissonance. Saleem, Ali dan Ahmad (2012) dalam penelitiannya terhadap mahasiswa di Amerika Serikat mengungkapkan hasil bahwa postpurchase dissonance terjadi akibat dampak dari pembelian impulsif dan keterlibatan sebuah produk tertentu. Sehingga apabila postpurchase dissonance terjadi dan konsumen tidak belajar dari pengalaman tersebut, maka konsumen berkemungkinan untuk melakukan pembelian secara impulsif lagi. Tentunya hal tersebut akan memunculkan kerugian secara finansial.

Selain terdapat faktor yang mempengaruhi postpurchase dissonance, terdapat juga beberapa dimensi untuk mengukur postpurchase dissonance menurut Sweeney, Hausknecht dan Soutar (2000). Salah satunya adalah wishdom of purchase (kebijaksanaan pembelian), yaitu kesadaran individu setelah melakukan pembelian. Apakah individu telah membeli produk yang tepat atau bahkan mungkin tidak membutuhkan sama sekali produk tersebut. Apabila individu merasa bahwa keputusan pembelian itu benar, tepat dan berguna, maka individu tersebut cenderung tidak akan mengalami postpurchase dissonance, begitu pula sebaliknya.

Di dalam penelitian ini terdapat adanya kelebihan dan kekurangan. Adapun kelebihannya adalah, tema yang diambil peneliti merupakan tema yang belum banyak dilakukan penelitian di lingkungan Universitas Muhammadiyah Malang. Adapun kekurangan dalam penelitian ini yaitu mengenai subjek penelitian, yang mana peneliti hanya mengambil subjek mahasiswa pengguna iPhone saja untuk diteliti. Sehingga hasil dari penelitian ini tidak dapat digeneralisasikan seluruhnya secara luas. Kekurangan yang lain adalah mengenai skala tipe kepribadian yang jumlah itemnya terlalu banyak, sehingga tak jarang subjek penelitian merasa bosan dan kurang fokus dalam mengisi skala penelitian yang diberikan. 
Berdasarkan hasil penelitian dengan uji independent sample $t$ test, dapat disimpulkan bahwa tidak ada perbedaan postpurchase dissonance mahasiwa pengguna iPhone ditinjau dari pola kepribadian tipe A dan B. Implikasi dari penelitian ini adalah bagi mahasiswa, diharapkan untuk lebih berhati-hati dalam proses keputusan pembelian suatu produk agar tidak mengalami postpurchase dissonance, apalagi dengan tingkat yang tinggi. Utamanya pada produkproduk yang memang bernilai tinggi. Dalam proses pembelian, ada beberapa hal yang perlu diperhatikan yaitu mengenai pengontrolan emosi, pengambilan keputusan dan gaya hidup. Namun ketika memang terjadi postpurchase dissonance, hal yang bisa dilakukan adalah dengan mengendalikan emosi dan mengambil pelajaran dari apa yang telah terjadi. Sehingga diharapkan pada kemudian hari individu tidak akan lagi mengalami hal yang sama. Karena dampak dari postpurchase dissonance ini dirasa cukup merugikan utamanya dalam hal finansial dari pihak produsen/penjual maupun pihak konsumen itu sendiri. Bagi peneliti selanjutnya, diharapkan dapat menggali lagi tentang postpurchase dissonance dengan variabel atau pendekatan kepribadian yang lain, misalnya dengan kepribadian bigfive, atau dapat juga melakukan penelitian kepada subjek yang memiliki rentangan usia dan profesi yang berbeda dari penelitian ini. Karena mungkin hasil dari penelitian yang didapatkan juga akan berbeda, sehingga nantinya dapat memberikan referensi teoritis dan wawasan yang leih luas dalam ranah keilmuan Psikologi yang kaitannya dengan perilaku konsumen. Kemudian peneliti selanjutnya jika ingin meneliti kaitannya dengan kepribadian tipe A dan tipe B, diharapkan agar menggunakan skala yang itemnya tidak terlalu banyak supaya subjek penelitian tidak merasa bosan dan tetap bisa fokus dalam mengisi skala penelitian yang disediakan.

\section{REFERENSI}

Alwisol. (2006). Psikologi Kepribadian (Ed.revisi). Malang: UMM Press.

Anonim. (2012). 1 dari 5 Warga Inggris Menyesal Beli IPhone. Diakses pada 23 Februari, 2016, dari http://gopego.com/news/a/2011/11/1dari5wargainggrismenyesalbeliiphone.

Agusta, A., \& Aris, M. (2011). Pengaruh Smartphone Terhadap Mahasiswa. Jurnal Teknik Informatika. Diakses pada Maret 11, 2019 dari https://www.scribd.com/doc/295115406/JurnalPengaruhSmartphone

Assael, H. (1984). Consumer Behavior and Marketing Action (Second Editon). New York: Kent Publishing Company.

Azwar, S. (2014). Metode Penelitian. Yogyakarta: Pustaka Pelajar.

Chebab, S. (2010). The Consumer Regret: Moderators, Mediators, and Consequences. Journal of Bussiness Studies Quarterly. 1(4), 4968.

Chesney, M. A., Eagleston, J. R., \& Rosenman, R. H. (1980). The Type A Structured Interview: A Behavioral Assessment in the Rough. Journal of Behavioral Assessment. 2, 225272.

Engel, J. F., Blackwell, R. D., \& Miniard, P. W. (1994). Perilaku Konsumen (Edisi Keenam). (Terj. F. X. Budiyanto). Jakarta: Binarupa Aksara.

Etherington, D. (2012, Sept 26th). Survey: iOS 6 Lead to Decrease in Device Satisfaction Among iPhone User. Retrieved February 23, 2016, from http://techcrunch.com/2012/09/26/surveyios6leadstodecreaseindevicesatisfactionamongip honeusers/.

Feldman, R.S. (1985). Social Psychology: Theories, research, and aplications. Singapore: McGrawHill Book Company. 
Friedman, H. S., \& Schustack, M. W. (2008). Kepribadian: Teori Klasik dan Riset Modern. (Terj. B. Widyasinta). Jakarta: Erlangga.

Gautam, O. (2015). Cognitive Dissonance: Dissonant Buying Behaviour of Consumer towards Cell Phones. Twelfth AIMS International Conference on Management, 322328.

Gay, L.R., \& Diehl, P.L. (1992). Research Methods for Business and Management. New York: MacMillan Publishing Company.

Haryanti, B. \& Ginting, E. D. J. (2013). Gambaran Postpurchase Dissonance Pada Konsumen City Car Honda Brio (Description of Postpurchase Dissonance on City Car Honda Brio Consumers). Jurnal Psikologi, 2, 18.

Hasan, U., \& Nasreen, R. (2012). An Indepth Analysis of Variables Affecting Post Purchase Cognitive Dissonance. Global Journal of Management and Business Research, 12 (20), 5458.

Hawkins, D. I., Best, R. J., \& Coney, K. A. (1998). Consumer Behavior: Building Marketing Strategy (Seventh Editon). USA: McGrawHill.

Hawkins, D. I., David, L. M., \& Best, R.. J. (2007). Consumer Behavior: Building Marketing Strategy (tenth Editon). New York City: Mc GrawHill.

Hendarto, V. D. (2014). Perbedaan Organizational Citizenship Behavior (OCB) Pada Pegawai Dengan Tipe Kepribadian A Dan B. Skripsi, Fakultas Psikologi Universitas Muhammadiyah Malang, Malang.

Jaenudin, U. (2012). Psikologi Kepribadian. Bandung: CV Pustaka Setia.

Jayanti, F. (2014). Dinamika Postpurchase Dissonance Pada Wanita Dengan Tipe Kepribadian Introvert. Skripsi, Fakultas Psikologi Universitas Sumatera Utara, Medan.

Kesumo, A. M., \& Rachmawati, I. (2015). Analisis Brand Equity iPhone di Indonesia 2015. Jurnal Managemen.

Munandar, A. S. (2012). Psikologi Industri dan Organisasi. Jakarta: UIPress.

Nurbaity, A. I. (2 Desember, 2014). Pengaruh Penggunaan Gadget di Kalangan Mahasiswa Universitas Atma Jaya Jakarta. Diakses pada 10 Maret 2016, dari http://adindaintannurbaity.blogspot.co.id/2014/12/pengaruhpenggunaangadgetdikalanga n.html

Pernando, D. (2010). Perbedaan Aspek yang Mempengaruhi Minat Berorganisasi antara Kepribadian Tipe A dengan Tipe B Anggota Komunitas Mahasiswa Universitas Islam Negeri Jakarta. Skripsi, Fakultas Psikologi Universitas Islam Negeri Jakarta, Jakarta.

Publisher, B. (Februari, 2016). Daftar Harga IPhone Apple Februari. Diakses pada 23 Februari, 2016, dari http://hariangadget.com/hargaiphoneapple/.

Rahmalia, D. (2017). Hubungan Shopping Lifestyle Dengan Postpurchase Dissonance Pada Remaja Di Kota Bandung. Skripsi, Fakultas Ilmu Pendidikan Universitas Pendidikan Indonesia, Bandung.

Saleem, M. A., Ali, R. A., \& Ahmad, S. (2012). Post Purchase Cognitive Dissonance: Impact of Product Involvement, Impulse Buying and Hedonic Consumption Tendencies. Interdisciplinary Journal of Contemporary Research in Business, 4 (5), 10511060.

Schiffman, L. G., \& Kanuk, L. L. (1994). Consumer Behavior (Fifth Editon). New Jersey: Prentice Hall.

Schultz, D. P., \& Schultz, S. E. (2006). Psychology and Work Today: An Introduction to Industrial and Organizational Psychology (Ninth Edition). USA: Pearson Education. 
Setiawan, I. (11 November, 2015). Sebelum Menyesal Jangan Beli iPhone Baca Dulu Artikel Berikut!!!. Diakses pada 11 Maret 2016, dari http://www.pemula.net/2015/11/sebelummenyesaljanganbeliiphone.html.

Siegel, L. S. (1994). Phenotypic performance profile of children with reading disabilities: A regressionbased test of the phonologicalcore variabledifference model. Journal of educational psychology, 86(1), 24.

Sitorus, G. M. (2007). Perbedaan Postpurchase Dissonance antara Konsumen dengan Tioe Keoribadian Ekstrovert dan Introvert. Skripsi, Fakultas Psikologi Universitas Sumatra Utara, Medan.

Solomon, M. R. (1999). Consumer Behavior: International Editon (Fourth Editon). USA: PrenticeHall.

Sugiyono. (2007). Statistika Untuk Penelitian. Bandung: CV Alfabeta.

Sweeney, J. C., Hausknecht, D., \& Soutar, G. N. (2000). Cognitive Dissonance After Purchase: A Multidimensional Scale. Journal of Psychology and Marketing, 17, 369385.

Tarigan, R. M. (2013). Dinamika Faktor Price sebagai Pemicu Postpurchase Dissonance pada Konsumen Perempuan. Skripsi, Fakultas Psikologi Universitas Sumatra Utara.

Wicaksono, A., Suharyono, \& Pangestuti, E. (2018). Pengaruh International Brand Image dan Lifestyle Terhadap Keputusan Pembelian: Survey Pada Pengguna Iphone Di Indocell Malang. Jurnal Administrasi Bisnis (JAB), Vol. 57 No. 2, 170179.

Wijono, S. (2012). Psikologi Industri \& Organisasi: Dalam Suatu Bidang Gerak Psikologi Sumber Daya Manusia (Ed.revisi). Jakarta: Kencana Prenada Media Group.

Winarsunu, T. (2009). Statistik Dalam Penelitian Psikologi \& Pendidikan. Malang: UMM Press. 